\title{
Does Decentralisation Improve Equity and Efficiency in Public Service Delivery Provision?
}

\section{Mark Robinson}

\begin{abstract}
1 Introduction
Many claims are made in favour of decentralisation, ranging from the democratising potential of increased scope for participation and accountability through to poverty reduction and improved service delivery. Much of the literature and evidence centres on the intrinsic value of decentralisation as a desirable goal in its own right. But the arguments for the developmental significance of decentralisation rest principally on a series of assumptions and theoretical justifications. Proponents of decentralisation base their assumptions on widely differing criteria, ranging from expected improvements in allocative efficiency, welfare and equity, through to increased participation, accountability and responsiveness on the part of local authorities. Economists tend to frame their analysis in terms of the costs and benefits of decentralisation, while other social scientists and practitioners are generally concerned with processes and democratic aspects of the process (Blair 2000).
\end{abstract}

This article focuses on substantive development outcomes, centred on how far decentralisation produces improvements in service delivery for the poor, drawing on evidence concerning equity and efficiency and the political and institutional conditions which give rise to these outcomes. The literature on democratic decentralisation and service delivery generally falls into two distinct categories: opportunities for enhanced popular participation and increased accountability of local authorities, or on forms of service delivery involving a plurality of actors. A major problem with the empirical literature is that there is no systematic or comparative evidence on whether increased participation in decentralised local governance generates better outputs in terms of improvements in the provision of health, education and drinking water and sanitation services for poor and marginalised people. The available evidence draws either on examples from single countries and sectors, or is anecdotal, temporally specific and highly localised, thus rendering the task of generalisation problematic. Similarly, efforts to measure development outcomes, in terms of reduced poverty or improved social indicators, and to attribute these to increased devolution and participation, are inconclusive and fraught with methodological problems (Crook and Sverrisson 2003; Dyer and Rose 2005).

These data constraints pose a serious challenge to advocates of participation and local governance, since the material benefits for the poor arising from improved service provision should be a key determinant of the effectiveness of democratic decentralisation. The intrinsic value of increased participation, accountability and responsiveness should not be underestimated, especially when political rights have been previously curtailed under centralised, authoritarian regimes. However, unless these process changes demonstrably translate into enduring improvements in service provision and material well-being, the claims made for the propoor potential of democratic decentralisation remain incomplete and cannot easily be sustained.

Some definitional issues are in order at this point. Decentralisation encapsulates three distinct elements: (1) fiscal decentralisation, entailing the transfer of financial resources in the form of grants and tax-raising powers to sub-national units of government; (2) administrative decentralisation (sometimes referred to as deconcentration), where the functions performed by central government are 
transferred to geographically distinct administrative units; (3) political decentralisation where powers and responsibilities are devolved to elected local governments; this form of decentralisation is synonymous with democratic decentralisation. Our concern in this article is mainly with democratic decentralisation, but several experiments in decentralised service delivery have involved the transfer of financial or administrative powers to subnational units of government that are not subject to democratic oversight through competitive elections. These variations in the form and content of decentralisation have an important bearing on processes of participation, accountability and responsiveness and in turn on service delivery outcomes.

The focus of this article is mainly on equity and social justice concerns, and some elaboration is required of the meaning and application of these terms with respect to service delivery. Equity outcomes have two main dimensions: access to services across different groups of the population on the basis of income, gender and other categories, and inter-regional equity in terms of disparities in access within and across local government jurisdictions (Litvack et al. 1998: 8). The provision of affordable, accessible and appropriate services to all categories of a population in equal measure is a universal standard for determining such outcomes, but a social justice perspective on service provision privileges the benefits that directly accrue to economically and socially marginalised groups (One World Action 1999, 2001).

Services are often equated with public goods like health, education, drinking water and sanitation and these tend to be the most common forms of services provided by local governments in developing countries. Police, fire, transportation, housing and social welfare services also fall under local government jurisdictions in many countries. Local governments are also given responsibility for a range of other public services, such as infrastructure in the form of roads and bridges, public buildings, and housing, especially in larger jurisdictions and urban authorities. In many countries, specialised services for low-income groups are the responsibility of local governments, such as social welfare, credit, and agricultural extension. Local authorities in rural areas often perform a range of functions directed at agriculture and rural development, environmental management, disaster prevention and rehabilitation.
Our focus in this article is principally on health and education as services that impact most directly on the well-being of the poor, as well as urban and rural infrastructure.

In most countries, public services are largely provided by the state, through government departments and specialised agencies, while private sector provision is becoming increasingly common in all areas of service provision as a result of state failure, and through privatisation and contracting-out that encourages market competition at the local level. Public service delivery is no longer the exclusive prerogative of state agencies in national and local governments, but involves combinations of state and private actors, and increasingly civil society organisations that are directly engaged in the delivery of services.

\section{Decentralisation and service delivery outcomes}

A leading rationale for decentralisation is that it can generate financial, efficiency and quality gains by devolving resources and decision-making powers to local governments for the delivery of services. It is financially attractive to national governments because part of the burden of financing services can be shifted to sub-national units and private providers which can produce these at lower cost. The allocative efficiency argument is that productivity of health, education and other services can be maximised by enabling local governments to take decisions on the allocation of scarce resources, since they have a better sense of local preferences. In the process, decentralised units of government can become more accountable in resource allocation decisions. It is further argued that the quality of service provision can also be enhanced by decentralisation since local governments will be more sensitive to variations in local requirements and open to feedback from users of services (Azfar et al. 2004: 21-4).

At the same time, the literature draws attention to the risks involved in decentralisation. First, there is no automatic assurance that increased political autonomy for local governments will lead to improvements in public services. Second, there is the well-known risk of capture by local political élites, which can worsen equity in the delivery of services. Third, the technical capacities of local government staff may be inadequate. Fourth, decentralisation can widen regional disparities in the provision of public 
services. Fifth, decentralisation poses macroeconomic risks by increasing government vulnerability to financial deficits and over-expanding the size of the public sector (Burki et al. 1999: 3-4).

Governments of very different ideological hues in Latin America, Africa and to a lesser extent, Asia, have experimented with decentralised service delivery over the past two decades. Initiatives have centred on the transfer of powers and resources to lower tiers of government, through a combination of measures involving a process of deconcentration to sub-national agencies operating under central line departments, and devolution of power and resources to elected local authorities. National governments have devolved responsibilities for different types of services across countries and jurisdictions accompanied by different degrees of fiscal decentralisation. It is therefore difficult to make generalisations across sectors and countries. For these reasons, the data on the impacts of decentralisation on service delivery outcomes are partial and incomplete, and some caution is required in the interpretation of available evidence in the absence of cross-national and cross-sectoral studies. In the remainder of this section, the available evidence from different parts of the world is reviewed, to determine whether any general lessons or patterns emerge on the relationship between political devolution and equity and efficiency outcomes.

\subsection{Latin America}

The decentralisation process has progressed furthest in Latin America, beginning with efforts in Chile and Colombia in the early 1980 s, to delegate increased responsibilities to municipalities (sub-national administrations) for the delivery of health and education services. These reforms emanated from a variety of domestic circumstances that differed between countries in the region. In some cases, conditions of resource scarcity brought about by macroeconomic crisis spurred countries to devolve responsibility to lower tiers of government (Prawda 1993). Governments in Colombia, Argentina and Brazil devolved powers to elected municipalities as part of a wider process of political liberalisation, whereas the military regime in Chile favoured administrative deconcentration to municipalities under the control of non-elected administrators appointed by the military (Nickson 1995). In Chile, where the reforms were far-reaching, the transfer of responsibility for primary and secondary education and primary healthcare to municipalities was accompanied by measures designed to expand private schools and healthcare facilities. According to Stewart and Ranis (1994), 'Municipal governments thus acted like "service delivery agents", providing local public services on a cost-effective basis, without having local governing power'.

Latin American municipalities deliver services in four ways: directly through municipal secretariats and departments; indirectly through municipally owned foundations; through enterprises owned by the municipalities or as joint ventures with the private sector; and through contracts to private companies or voluntary agencies (Nickson 1995). The absence of comparative data on the equity impact of decentralised service delivery in Latin America makes it difficult to derive well-founded conclusions, but there is some cross-country data available for particular sectors.

Prauda's comparative review of educational decentralisation in four Latin American countries in the 1980s - Argentina, Chile, Colombia, and Mexico provides some insights into the equity and efficiency impacts of these reforms (Prawda 1993). From this comparative analysis Prawda concluded that decentralisation of education did not lead to discernible quality improvements, but rather produced negative equity effects, with the result that the gap between better off and worse off schools actually widened. Educational expenditures fell in three of the four countries (with the exception of Argentina) on account of sharp decreases in teachers' salaries, under conditions of fiscal austerity, which may well have impacted adversely on teaching quality.

Four key lessons arise from Prawda's review: (1) educational decentralisation does not automatically accomplish productivity, equity, and quality improvements; (2) it requires a lengthy gestation period before it starts producing benefits; (3) continuous changes of senior personnel in central and local administrations are inimical to reform; and (4) an expansion in private provision has widened the performance gap between schools and income groups (Prauda 1993: 262). He argues that fiscal incentives should be built into the decentralisation process to stimulate the performance of local governments by rewarding local revenue-raising efforts and penalising severe budgetary deficits. 
Chile is the only Latin American country for which data is available on cognitive achievement in selected subjects, which serves as a proxy for determining the impact of the reforms on quality and equity in education provision. According to Prawda, 'as measured by cognitive achievement results, it is quite clear that quality did not improve in the 1982-1988 period. It is also clear that inequity widened significantly at that time' (Prawda 1993: 258). These findings are corroborated by Parry, who found that decentralisation and privatisation have exacerbated the negative consequences of educational decentralisation, resulting in greater inequity in expenditures and greater differences in the performance of students from different income groups (Parry 1997: 116-7). Declining real per capita expenditures and competition for students between municipal and private schools also had some negative consequences for equity in the 1980 s but remedial measures introduced by civilian governments after 1992 counterbalanced these trends (Parry 1997: 128-9). Municipal councils and mayors are now elected and municipalities have been provided with additional funds to cover service outlays, but discretionary power to raise additional resources remains limited (Stewart and Ranis 1994).

Regarding healthcare, evidence from six Latin American countries indicates that the quality of service provision has worsened under decentralisation. Transfer of financial resources and staff to lower levels of government neither improved service delivery nor reduced the costs of care (Burki et al. 1999: 75-86). Chile provides some evidence on the equity effects of decentralisation and privatisation of healthcare provision under the military regime in the 1980s (Gideon 2001). One review concluded that 'In general, the transfer of primary care clinics to municipalities has not resulted in extending coverage or in improving the quality of services, largely because of a lack of professional supervision and poor health planning by the area health services' (Montoya-Aguilar and Vaughan 1990). Despite vigorous efforts to promote private health provision and to delegate responsibility for public healthcare provision to the municipalities, two-thirds of all medical consultations and 80 per cent of hospitalisations were still statefunded in the mid-1990s, supported by 7 per cent tax on earnings and pensions. Problems continued to affect the quality of public healthcare provision through municipalities, despite measures to improve targeting and resourcing: 'Although low-income earners receive "free" healthcare, "access is difficult, waiting times are long, services are of poor quality, and facilities and provision of pharmaceuticals meager"' (Gillion and Bonilla, cited in Tankersley and Cuzán 1996: 113). However, since it is difficult to disaggregate the effects of decentralisation from privatisation and fiscal constraints the problems of public health provision under the municipalities cannot easily be attributed to local administrative arrangements alone.

Colombia is the one other Latin American country for which evidence on the impact of decentralisation on service delivery is available. In response to growing social protests over the declining quality of public services, the Colombian government devolved responsibility for public services to elected municipalities, and sharply increased intergovernmental transfers and revenue-raising powers from the late 1980s (Forero and Salazar 1991: 122). Local governments assumed responsibility for the provision of services in education, health, water, sanitation, roads and agricultural extension. The evidence suggests that satisfaction levels with municipal governments increased after the introduction of direct elections for mayors in 1988. Case studies of individual municipalities and opinion surveys 'found evidence of increased service coverage, citizen satisfaction, attention to rural areas and the poor, cost consciousness and resource mobilization efforts' (Fiszbein 1997: 1030). There is some evidence from this research of a positive relationship between the strength of community participation and government performance: municipalities that followed a more open and inclusive approach to policymaking were positioned to achieve better outcomes. The majority of individuals surveyed in a sample of 16 municipalities believed that municipal governments play a central role in the provision of education, water and roads. An overwhelming majority reported greater trust in local than national government and a larger number of individuals prefer the municipal government to be in charge of overall service provision (Fiszbein 1997: 1035). Municipalities assumed responsibility for public education after 1991 with the formation of councils composed of teachers, parents and students to run local schools. Councils were given the right to elect principals, but hiring remained under the control of the Ministry of Education. Autonomous regions, communities and schools were given power to adapt curricula, raising concerns about fragmentation (Astiz et al. 2002: 75). 
Comparative evidence on health and educational decentralisation in Latin America in the 1980s and 1990s points to several conclusions. First, it is difficult to derive hard and fast generalisations on the basis of partial and incomplete evidence. Second, the implications for equity have been negative, with divergences between poorer and wealthier groups in accessing health and educational services. This finding is consistent with the broader literature on educational decentralisation. In this respect, Dyer and Rose (2005: 107) state, 'The assumed benefits of decentralisation are ... contested in relation to equity, for which it is often found to have negative consequences. Decentralization can widen quality differences between schools, and performance gaps between students, in wealthy and poor areas'. Similar observations hold true for the health sector. Third, as the contrasting cases of Chile and Colombia demonstrate, political and institutional conditions have a significant bearing on decentralisation outcomes and levels of user satisfaction. This point is taken up at greater length in the concluding section of the article.

\subsection{Sub-Saharan Africa}

The evidence from sub-Saharan Africa is very limited and even more qualified as regards the equity impact of decentralised service delivery (Conyers, in this IDS Bulletin). Despite the inclusion of decentralisation in public sector reform efforts in the 1980s and early 1990s by countries such as Uganda, Botswana, Nigeria, Ghana, Côte d'Ivoire, Kenya and Tanzania, one leading commentator has stated that 'there are no real success stories as far as improved development performance at the local level is concerned' (Adamolekun, cited in Francis and James 2003). This stark finding is corroborated by Wunsch (2001), who attributes to failure of decentralisation in Africa to problems such as the over-centralisation of resources, limited transfers to sub-national governments, a weak local revenue base, lack of local planning capacity, limited changes in legislation and regulations, and the absence of meaningful local political process. These dismal assessments are reflected in studies of local governance and decentralised service provision from a number of countries in the region (Olowu and Wunsch 2004).

Uganda is one African country that has pursued a potentially far-reaching decentralisation experiment since the late 1980s, with increased availability of resources for national social service programmes, especially for education, health and drinking water infrastructure channelled through local councils. But the evidence suggests that 'Decentralization has not been able to arrest the deterioration in agricultural services, and that the improvements in social services are attributable to increases in central conditional funding rather than the very limited scope which decentralized institutions have provided for local decision making' (Francis and James 2003: 333).

In Côte d'Ivoire, new opportunities were created for popular participation through the introduction of multi-party competition for local council (commune) elections, but the mayors continued to exert overriding control and influence. As a result, the preferences expressed by local people for roads, social facilities and water supplies did not correspond to spending priorities of the communes, which focused on municipal buildings and secondary schools. In any case, most commune development programmes collapsed in the face of public spending cuts during the financial crisis of the early 1990s. It is therefore unsurprising that only one-third of those interviewed in four sample communes felt that the communes addressed their development needs (Crook and Sverrisson 2001: 26). A similar finding emerged from Ghana, where survey evidence from two districts demonstrated that 70 per cent of respondents felt that the elected assembly did not respond to their needs. Expressed preferences for road repairs, health facilities, water supplies and electricity were not reflected in district assembly expenditure priorities which focused on commercial transport services, farming, manufacturing enterprises or markets, a situation exacerbated by the dominance of recurrent expenditures in district budgets (Crook and Sverrisson 2001: 32). In Nigeria, a study of primary healthcare in the early 1990 s revealed a complete lack of real participation in decision making despite devolution of responsibility to elected local officials. Local residents saw primary healthcare as unreliable, ineffective and unresponsive to their needs, while councillors were unclear of the health needs of their constituents, and had little knowledge of health plans and activities (Crook and Sverrisson 2001: 32).

This brief review indicates that the evidence on the service delivery outcomes in Africa is even more slender than for Latin America. Moreover, from the limited evidence that exists, there is little to indicate that the various decentralisation experiments under 
way across the continent are generating the expected development dividends and that citizens have yet to see any real improvement in service quality.

\subsection{South Asia}

Evidence from Asia is very limited, largely because decentralisation initiatives in countries of the region are more recent in origin, and because in most South Asian countries, health and education services have only been devolved to a limited extent. There are few comparative studies of service delivery outcomes resulting from decentralisation in the region, and limited insights from sector experience in particular countries. Recent country studies of healthcare spending under decentralisation in China, India, Indonesia and the Philippines point to a decline or stagnation after decentralisation started in these countries. In China and India, local governments were unable to fulfil their new responsibilities for healthcare provision in the absence of inadequate resource transfers from central government. But in contrast, health outcomes in Indonesia and the Philippines improved significantly during decentralisation, reflected in a sharp decline in the under-five mortality rate, largely because of reforms in healthcare funding (OECD 2006).

Drawing on survey data from 33,000 households in villages across India, Mahal et al. (2000) demonstrate that decentralisation of public service delivery in primary healthcare and education services is positively correlated with improved child mortality and school enrolment. However, health and education services in India are generally under the jurisdiction of state governments and local councils have limited influence over the use of resources or deployment of personnel. Elected councils have limited discretion over the use of resources for developmental purposes, which are largely earmarked for schemes and programmes determined by state and central governments. It is only in the Indian states of West Bengal and Kerala that decentralisation of expenditures for basic services has taken place on a significant scale, by placing substantial untied funds at the discretion of local village councils for developmental purposes. In the West Bengal case, sample evidence points to improvements in access to administrative and justice systems and water provision in some areas, amid an overall improvement in agricultural productivity and reduction in poverty levels in the 1980s, though it is difficult to attribute these outcomes to decentralisation and increased powers and resources for elected local councils (Crook and Sverrisson 2003: 243). Preliminary evidence from Kerala's Popular Planning Campaign launched in 1996 indicates that local council expenditures more accurately reflected local preferences, and investments in infrastructure were more oriented towards the needs of the poor (Isaac with Franke 2000; Chaudhuri and Heller 2002).

By comparison, successive decentralisation schemes in Bangladesh have all failed to deliver improved services. According to Crook and Sverrisson (2001: 46), 'Material welfare, in terms of agricultural output, did not increase, there was little evidence of greater equity at grassroots level, and a number of studies indicated that the beneficiaries were the rich and the well-born. Instead, decentralization was generally seen as a means to channel development resources into the hands of the better off'.

Responsibility for implementation of disaster relief programmes was devolved to local councils under the military government in the mid-1980s, but with negative impacts: flood rehabilitation programmes suffered from poor management, maldistribution, corruption and shortages of resources, while few very poor households received any benefits from rehabilitation schemes that tended to focus on roads, bridges and buildings.

This brief and partial review of the experience of decentralised service delivery leads to the following tentative conclusions. First, improved equity outcomes have generally not been realised for poor and socially marginalised people. Second, the quality of public service provision has not improved as a result of the devolution of power and resources to local governments. The gap in quality between wealthier and poorer areas has often increased under decentralisation. Third, efficiency gains have been realised, usually as a result of the delegation of financial responsibility for service provision from central to local governments, but resources have not been adequate to ensure effective coverage and quality.

\section{Improving equity through decentralised service delivery}

It is tempting to draw the conclusion that equity and social justice objectives are not well served by decentralised service provision, and that centralised provision through deconcentrated state agencies is a preferable approach (Johnson 2001; 
Schneider 2003). At the same time, the available evidence confirms that increased participation and better accountability can result from democratic decentralisation, and that these substantive benefits should not be underestimated (Crook and Manor 1998; Blair 2000). A poor record on service delivery to date does not rule out the scope for improved equity and efficiency outcomes. Rather, the challenge is to identify the conditions under which increased participation in local governance is conducive to enhanced equity, quality and efficiency of services. This will almost certainly require further comparative research but it is possible to outline a schema in which the potential for improvement rests on a combination of political, institutional, financial and technical factors.

\subsection{Political commitment and leadership}

Political factors are of intrinsic importance to decentralised service delivery for several reasons. It is widely accepted that political commitment on the part of federal or state governments is a sine qua non of effective democratic decentralisation, and especially forms of decentralisation that are specifically geared to the interests of the poor (Crook and Sverrisson 2001; Blair 2000). Successful pro-poor decentralisation is associated with governing parties that are politically committed to the democratic empowerment of local governments (Heller 2001; Escheverri-Gent 1993).

The Indian state governments of West Bengal and Kerala evince a strong commitment to decentralisation, reflected in supportive legislation and a significant flow of resources to lower levels of government. In Colombia successive governments from the mid-1980s have systematically devolved powers and resources to municipalities, with positive consequences for service delivery. Brazilian experience demonstrates how political commitment at the level of individual municipalities can explain a propensity for pro-poor reform initiatives, such as the participatory budgeting process in Porto Alegre and other municipalities (Baiocchi 2001; Heller 2001). In contrast, evidence from Africa and other Latin American countries demonstrates that weak political commitment to decentralisation opens up the possibility of élite capture, limits the scope for participation, and results in ineffective outcomes (Smith 1985).

Political leadership also plays an important role in shaping service delivery outcomes, since politicians in local governments do not respond with equal vigour to the opportunities presented by high-level political commitment to democratic decentralisation. This is especially important in local administrations with powerful, directly elected mayors who have the authority to effect or block change mandated by higher level political authorities. For instance, in the Colombian case, mayors committed to deepening the process of municipal decentralisation through public consultation, and enhanced resource flow registered higher levels of public satisfaction with service delivery outcomes. According to Fiszbein (1997: 1032), 'competition for political office opened the doors to responsible and innovative leadership that became the driving force behind capacity building. It was the combination of the added responsibilities, more resources and political reforms that created the environment conducive to the emergence of effective local governments'.

\subsection{Political mobilisation of the poor}

The political impetus for democratic decentralisation created by reform-minded political parties can create opportunities for collective action from below by mobilising constituencies that are traditionally excluded from national policymaking arenas. This can entail mobilisation of cadres and supporters by political parties in local constituencies, and mobilisation of the poor by civil society organisations (NGOs, trade unions and social movements) to take advantage of political openings from above and to articulate public protest and dissent.

Party-based mobilisation can assume two forms in the context of democratic decentralisation: mobilisation of people though local units of political parties for electoral purposes and mobilisation of supporters to ensure effective implementation of reform initiatives. Democratic decentralisation usually entails the devolution of power to elected local authorities, which in turn widens the scope of political participation at the local level (Robinson 1998). In many Latin American countries, municipalities were traditionally run by non-elected administrators appointed by military or authoritarian regimes. Legislation introduced from the 1980s led to the creation of elected mayors and local councils, providing opportunities for political mobilisation around competing policy agendas. However, political parties are not always allowed to contest local elections (e.g. Uganda, India and Pakistan), which must be contested on an individual or no-party basis, 
thus limiting the scope for party-based mobilisation. However, in Brazil, Kerala and West Bengal, local government elections serve as a basis for partybased mobilisation around competing political agendas, though the extent to which these hinge on service delivery issues is not apparent.

Civil society organisations also mobilise constituencies in local government jurisdictions to take advantage of increased powers and resources, to mobilise people to take part in consultative arenas, and to engage in public protest over the quality of public services. In Kerala, a prominent social movement (Kerala Sastra Shitya Parishad - the People's Science Movement) played a critical role in shaping and implementing the People's Campaign for Decentralized Planning in the late 1990s, though this has not been replicated elsewhere in India (Isaac with Franke 2000; Chaudhuri and Heller 2002). Civil society mobilisation in response to increased powers to local governments is particularly marked in Latin America, which may reflect traditions of political resistance to authoritarian rule, but also resource availability at the local level. Social movements and trade unions played a part in mobilising protest over the state of municipal services in Colombia in the 1970s, which served as a catalyst for subsequent reform of local government. In the city of Cochabamba in Bolivia, civil society organisations helped to articulate public demonstrations over water privatisation and service charges, resulting in remedial measures by the municipal administration. Similarly, several South African municipalities have witnessed civil society-led protests over service standards and fees.

\subsection{Institutionalised participation}

Local authorities in different countries have experimented with institutional arrangements designed to facilitate public engagement, feedback and oversight in recognition of the latent power of organised civic protest. These include consultative bodies designed to provide citizen oversight over particular services, taking the form of health councils and school boards. Prominent Latin American examples include the local administrative boards in Colombia, local area boards in São Paolo and the neighbourhood councils of Montevideo, through to more ambitious exercises designed to elicit participation in decisions concerning priority setting and resource allocations, exemplified by the participatory budgeting exercises in Porto Alegre and other Brazilian cities (Nickson 1995: 86-9).
Critics argue that such bodies serve to undermine popular resistance and oversight, while their proponents claim that institutionalised participation facilitates and widens public engagement at the local level in policy deliberation, planning and implementation. However, in the absence of any comparative evidence it is difficult to ascertain either the prevalence of these bodies or their effectiveness in influencing resource allocations or service standards.

\subsection{Adequacy of financial resources}

The availability of financial resources is a critical determinant of the equity, quality and efficiency of public services, and the inadequacy of financial resources often contribute to poor service delivery outcomes. Devolution of responsibility for service provision to local governments is usually accompanied by some element of financial decentralisation through resource transfers, usually as a share of central taxation, or enhanced powers to raise revenues through a variety of local taxes (Bahl and Linn 1994; Bird and Vaillancourt 1999). Fiscal decentralisation often renders local governments vulnerable to macroeconomic shocks and remedial measures to control public expenditures and national budget deficits. Several Latin American countries experienced this phenomenon in the 1980s because of economic stabilisation measures, which sharply reduced spending on the social sectors and the value of transfers to local governments. The quality and reach of public services is bound to suffer in the absence of complementary measures to raise local resources. The financial imperative has been a key factor underlying municipal privatisation initiatives and the introduction of cost-sharing measures in the form of user fees in local governments around the world (Mawabu et al. 2001).

Another dimension of resource availability centres on the financial powers of local governments. Salaries and recurrent expenditures tend to account for a large share of local government outlays on services, especially in the health and education sectors, with more limited resources available for capital expenditures. Limited scope for discretionary allocations across budget heads further restricts the budgetary autonomy of local governments. Local governments may also receive financial transfers that are earmarked for certain programmes or pre-assigned categories of expenditure. In India, for example, local bodies receive grants-in-aid from state and central government that are tied to specific anti- 
poverty and social welfare programmes, while recurrent expenditures account for a very high proportion of health and education budgets. The financial autonomy of local governments is thus highly constrained. A major exception is Kerala, where the elected local councils have discretion over 40 per cent of the state development budget, subject to broad guidelines on different categories of expenditure, which provides them with substantial scope to respond to locally determined development priorities.

\subsection{Technical and managerial capacity}

The provision of public services can be an enormously complex exercise, especially in urban municipalities with large populations, and often requires a high level of technical and managerial capacity. However decentralisation of responsibility for service provision has not always been accompanied by measures to ensure effective capacity for planning, budgeting, implementation and monitoring in local governments, all of which have a critical bearing on service quality. Efforts to strengthen the professional and technical skills of local government employees and to improve the internal organisation and management style of local administration are often central to building such capacity (Fiszbein 1997; Dyer and Rose 2005).

Managerial and technical capacity is not only a key determinant of the performance of local officials in relation to service delivery, but also influences their behaviour towards users of services. Centralised service delivery through hierarchically organised line departments and deconcentrated agencies gives rise to behavioural norms that may not be conducive to participation and greater responsiveness. Creating an organisational culture in local government that is more citizen-friendly and receptive to active community involvement, as well as performance oriented, requires a combination of incentives and focused capacity-building measures to complement the strengthening of technical and managerial skills.

\section{Conclusion}

This article has sought to ascertain the impact of decentralised service delivery on equity and efficiency outcomes. Subject to constraints of data availability, two main conclusions arise from a review of available evidence in less-developed countries: (1) the quality and equity of access have not improved with the decentralisation of health and education services; and (2) equity and efficiency outcomes are closely related to the availability of financial resources and local government capacity.

These insights tend to give rise to two types of policy prescription, neither of which is closely compatible with democratic decentralisation: (1) health and education services are better administered by deconcentrated public agencies working under the direct control of central line departments, and (2) expanding the role of private providers and introducing user fees can improve quality and efficiency of resource use. However, experience suggests that while efficiency gains may be realised, neither of these approaches is conducive to participation in local governance, nor are they guaranteed to produce outcomes that are more favourable to equity and social justice objectives.

The challenge for proponents of democratic decentralisation is to specify methods and approaches by which equity objectives can be realised under decentralised forms of service delivery. Successful interventions are not premised on participation and accountability alone, but require attention to political factors (such as commitment, leadership and mobilisation), institutional arrangements, financial resources and technical and managerial capacity. Greater emphasis should be given to measuring and monitoring service delivery outcomes under decentralised forms of provision, to ensure that participation in local governance produces real gains for the poor in terms of improved access and quality of services. Failure to do so will undermine the allure of democratic decentralisation and encourage policy alternatives that run counter to the ethos of participation in local governance and the potential for improving service provision for the benefit of the poor. 


\section{References}

Astiz, M.F., Wiseman, A.W. and Baker, D.B. (2002) 'Slouching Towards Decentralization: Consequences of Curricular Control in National Education Systems', Comparative Education Review 46.1: 66-88

Azfar, O., Kähkönen, S., Lanyi, A., Meagher, P. and Rutherford, D. (2004) 'Decentralization, Governance and Public Service: The Impact of Institutional Arrangements', in M.S. Kimenyi and P. Meagher (eds), Devolution and Development: Governance Prospects in Decentralizing States, Aldershot: Ashgate

Bahl, R. and Linn, J. (1994) 'Fiscal Decentralization and Intergovernmental Transfers in Less Developed Countries', Publius - Journal of Fiscal Federalism 24.1: 1-19

Baiocchi, G. (2001) 'Participation, Activism and Politics: The Porto Alegre Experiment and Deliberative Democratic Theory', Politics and Society 29.1: 43-72

Bird, R. and Vaillancourt, F. (eds) (1999) Fiscal Decentralization in Developing Countries, Cambridge: Cambridge University Press

Blair, H. (2000) 'Participation and Accountability at the Periphery: Democratic Local Governance in Six Countries', World Development 28.1: 21-39

Burki, S.J., Perry, G.E. and Dillinger, W.R. (1999) Beyond the Center: Decentralizing the State, Washington DC: The World Bank, World Bank Latin American and Caribbean Studies

Chaudhuri, S. and Heller, P. (2002) 'The Plasticity of Participation: Evidence from a Participatory Governance Experiment', mimeo, Department of Economics, Columbia University

Crook, R.C. and Manor, J. (1998) Democracy and Decentralisation in South Asia and West Africa: Participation, Accountability and Performance, Cambridge: Cambridge University Press Crook, R.C. and Sverrisson, A.S. (2003) 'Does Decentralisation Contribute to Poverty Reduction? Surveying the Evidence', in P.P. Houtzager and M. Moore (eds), Changing Paths: International Development and the New Politics of Inclusion, Ann Arbor: University of Michigan Press: 233-59

Crook, R.C. and Sverrisson, A.S. (2001) Decentralisation and Poverty-Alleviation in Developing Countries: $A$ Comparative Analysis or, is West Bengal Unique?, IDS Working Paper 130, Brighton: IDS

Dyer, C. and Rose, P. (2005) 'Decentralisation for Educational Development? An Editorial Introduction', Compare 35.2: 105-13
Escheverri-Gent, J. (1993) The State and the Poor: Public Policy and Political Development in India and the United States, Berkeley and Los Angeles: University of California Press

Fiszbein, A. (1997) 'The Emergence of Local Capacity: Lessons from Colombia', World Development 25.7: 1029-43

Forero, H. and Salazar, M. (1991) 'Local Government and Decentralization in Colombia,' Environment and Urbanisation 3.2: 121-6

Francis, P. and James, R. (2003) 'Balancing Rural Poverty Reduction and Citizen Participation: The Contradictions of Uganda's Decentralization Program', World Development 31.2: 325-37

Gideon, J. (2001) 'The Decentralization of Primary Health Care in Chile', Public Administration and Development 21.3: 223-31

Heller, P. (2001) 'Moving the State: The Politics of Democratic Decentralisation in Kerala, South Africa, and Porto Alegre', Politics and Society 29.1: 131-63

Isaac, T. with Franke, R.W. (2000) Local Democracy and Development: People's Campaign for Decentralized Planning in Kerala, New Delhi: LeftWord

Johnson, C. (2001) 'Local Democracy, Democratic Decentralisation and Rural Development: Theories, Challenges and Options for Policy', Development Policy Review 19.4: 521-32

Litvack, J., Ahmad, J. and Bird, R. (1998) Rethinking Decentralization in Developing Countries, Washington DC: The World Bank, Poverty Reduction and Economic Management Network Mahal, A., Srivastava, V. and Sanan, S. (2000) Decentralization and Public Sector Delivery of Health and Education Services: The Indian Experience, Discussion Papers on Development Policy 20, Bonn: Centre for Development Research, University of Bonn

Montoya-Aguilar, C. and Vaughan, P. (1990) 'Decentralization and Local Management of the Health System in Chile', in Mills, A., Vaughan, J.P., Smith, D.L. and Tabibzadeh, I. (1990) Health System Decentralization: Concepts, Issues and Country Experience, Geneva: World Health Organization (WHO): 55-63

Muabu, G., Ugaz, C. and White, G. (eds) (2001) Social Provision in Low-income Countries: New Patterns and Emerging Trends, Oxford: Oxford University Press

Nickson, R.A. (1995) Local Government in Latin America, Boulder: Lynne Rienner 
Olowu, D. and Wunsch, J.S. (eds) (2004) Local Governance in Africa: The Challenges of Democratic Decentralisation, Boulder: Lynne Rienner

One World Action (2001) Developing Gender-Sensitive Local Services, report of a seminar organised by One World Action and the British Council

One World Action (1999) Influence and Access - Local Democracy and Basic Service Provision, report of a seminar organised by One World Action

OECD (Organisation for Economic Co-operation and Development) (2006) Decentralisation in Asian Health Systems: Friend or Foe?, Policy Insights 18, Paris: OECD Development Centre, May

Parry, T.R. (1997) 'Decentralization and Privatization: Education Policy in Chile', Journal of Public Policy 17.: 107-33

Prawda, J. (1993) 'Educational Decentralization in Latin America: Lessons Learned', International Journal of Educational Development 13.3: 253-64

Robinson, M. (1998) 'Democracy Participation and Public Policy: The Politics of Institutional Design', in M. Robinson and G. White (eds), The Democratic Developmental State: Politics and Institutional Reform, Oxford: Oxford University Press

Schneider, A. (2003) Who Gets What from Whom? The Impact of Decentralisation on Tax Capacity and Pro-Poor Policy, IDS Working Paper 179, Brighton: IDS

Smith, B. (1985) Decentralisation: The Territorial Dimension of the State, London: George, Allen and Unwin

Stewart, F. and Ranis, G. (1994) Decentralization in Chile, Occasional Paper 14, New York: United Nations Development Programme, Human Development Report Office

Tankersley, W.B. and Cuzán, A.G. (1996) 'Privatization and Decentralization in the United States and Chile', Journal of Developing Societies XII.1: 104-18

Wunsch, J.S. (2001) 'Decentralization, Local

Governance and "Recentralization" in Africa', Public Administration and Development 21.4: 277-88 